Article

\title{
Iris Marion Young's 'Faces of Oppression' and the Oppression of Women in the Responsible Parenthood and Reproductive Health Act of 2012
}

Marella Ada V. Mancenido-Bolaños

\begin{abstract}
In this paper, I wish to argue that it is necessary to have an earnest understanding of the plight of women before crafting laws that directly impact their lives. Against the backdrop of my discussion is the notion of "oppression" offered by Iris Marion Young in her book Justice and Politics of Difference. I recount Young's description of the "faces of oppression" and use her notion of oppression to show that the process of policy-making in the Philippines is mired by the oppressive dominance of patriarchal bias. In her book, The RH Bill Story: Contentions and Compromises, Marilen J. Dañguilan provides the most comprehensive study of the role that Filipina women played during the drafting of the 1987 Philippine Constitution and The Responsible Parenthood and Reproductive Health Act of 2012. I draw on the work of Dañguilan in order to cite instances of oppression of women in policy making.
\end{abstract}

Keywords: Young, Dañguilan, faces of oppression, RPRH Act of 2012

"The philosopher is always socially situated, and if society is divided by oppressions, she either reinforces or struggles against them."

-Iris Marion Young

\section{Introduction}

n 2004, after I received my baccalaureate degree, I took on a job as a staff at the Philippine NGO Council for Population, Health and Welfare. Here, II was immediately exposed to issues on family planning, HIV advocacy programs, and programs to battle violence against women and children. I then realized that academic feminism is not enough to push for the rights of 
women. There is thus a need to work with women in the community if the intention is to help them address their life situations. In the academe, we write about women and the other, women's body and their choices, and women in the patriarchal society; in the community, however, we see how all these things are happening-how women are not able to take full control of their bodies, how they continue to submit to patriarchy, and how their plight is largely considered by government and society as secondary.

In "Gender as Seriality: Thinking About Women as a Social Collective," 1 Iris Marion young suggests that "the primary task of feminist theory and politics is critical: to formulate genealogies that show how a given category of practice is socially constructed." 2 She adds that "feminist discourse and practice should become and remain open, its totality permanently deferred, accepting and affirming the flows and shifts in the contingent relations of social practices and institutions." ${ }^{3}$ This serves to caution future feminists to avoid "excluding some women from its theories," 4 as there are instances when a theory only speaks for the privileged. This idea likewise extends to policymaking, because some women are excluded from the construction of these policies, especially when the members of the policymaking body are privileged people who could not identify with the plight of common women.

Young argues that, when conceptualizing about women, we must think of them as a group. This will allow us to understand oppression as a systematic, structured, and an institutional process. ${ }^{5}$ She adds that the affirmation of women as a group unites women because it stops them from believing that their sufferings are natural or merely personal. ${ }^{6}$ However, instead of a thinking of a group in which all differences are dissolved, Young follows Ann Ferguson who claimed that "it may be more helpful to posit different racial gender positions, and possibly different class gender positions." 7 It matters to consider these nuances because people do not look at women fairly. A white woman may be regarded better than a woman of color, in the same way that a working-class woman is treated differently compared to a professional woman.

\footnotetext{
${ }^{1}$ See Iris Marion Young, "Gender as Seriality: Thinking About Women as a Social Collective," in Signs, 19:3 (1994).

${ }^{2}$ Ibid., 716.

${ }^{3}$ Ibid.

${ }^{4}$ Ibid., 717.

${ }^{5}$ Ibid., 718.

${ }^{6}$ Ibid.

${ }^{7}$ Ann Ferguson, "Is There a Lesbian Culture?" in Lesbian Philosophies and Culture, ed. by Jeffner Allen (Albany: State University of New York), 114-115. See also Young, "Gender as Seriality," 720.
}

(c) 2020 Marella Ada V. Mancenido-Bolaños https://www.kritike.org/journal/issue 26/mancenido-bolanos june2020.pdf ISSN 1908-7330 
To address this problem, Young used Jean-Paul Sartre's concept of seriality. She discussed gender as a social series which provides a "way of thinking about women as a social collective without requiring that all women have common attributes of common situation." 8 Young differentiates the group from the series, stating that a group is a unity of individuals who are able to acknowledge that they may undertake a common project together. A series, on the other hand, is considered as a social collective wherein they may be united by the same end or material object, the same history and identity, but do not necessarily have the same action and goals. ${ }^{9}$ Serial collectivity can be understood as the "obverse of the mutual identification of the group; each goes about his or her own business, but each is also aware of the serialized context of that activity." 10 In serial collectivity, a woman is not defined by single category alone; by serializing gender, we can avoid the problems that emerge from saying that women form a single group and it also disconnects gender from identity. ${ }^{11}$ It is important to understand that groups are formed out of a serialized condition. ${ }^{12}$ Women's advocacy groups, for example, came into existence because of a serialized condition of women, e.g., violence against women or poor reproductive health care. It would be apt to say that serial collectivity shatters the ground of race, gender, and class because each individual is taken into account without defining him/her as a member of one particular group. The formation and distinction of groups could eventually lead to unjust relationships among people in the community. Young, in her book Justice and the Politics of Difference, notes that justice is not just about distribution but also the necessary condition that enables an individual to exercise his/her capacities and collective communication and cooperation. She adds that "injustice refers primarily to two forms of disabling constraints, oppression and domination." 13

For Young, oppression is structural, since its causes are deeply embedded in "unquestioned norms, habits, symbols, in the assumptions underlying institutional rules and the collective consequences following those rules." 14 It exists in our everyday lives with some oppressors being unconscious of their oppressive actions, partly because such actions and reactions have already been part of their systemic understanding, while some oppressors bear conscious intentions to oppress. There are those who resist oppression, while others willingly submit to it, because the oppressive

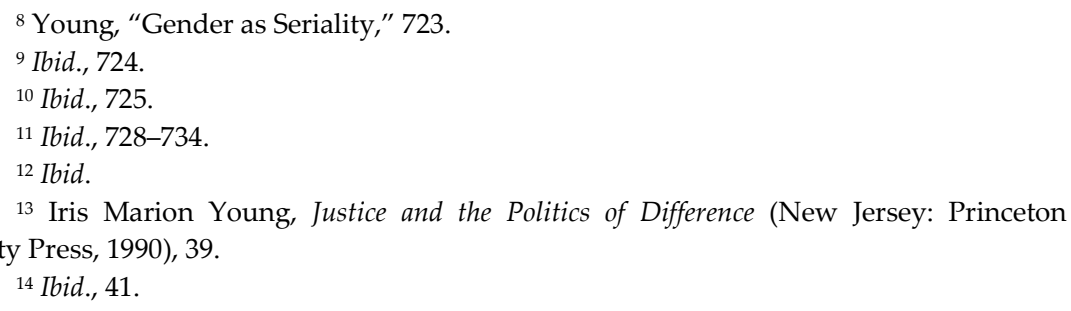


relation is somehow beneficial for them. Young rightly claims that "for every oppressed group there is a group that is privileged in relation to that group." 15

A social group can be understood as a collective individual "differentiated from at least one other group by cultural forms, practices or way of life." 16 Members of the group identify with each other because a common experience binds them together. Young argues that this is because of the formation of groups that oppression takes place, one's association with a group excludes him/her from another group. However, groups should not be extinguished just because we want oppression to stop. This kind of affinity is important because "group differentiation is both an inevitable and desirable aspect of the modern social process. Social justice ... requires not the melting away of difference, but institutions that promote reproduction of and respect for group differences without oppression." 17 We can only hope for that such form of social justice is achievable.

Young holds that members of the groups make use of the term oppression to describe their experiences of injustice. She claimed that "oppression names in fact a family of concepts and conditions" 18 which she divided into five categories: "exploitation, marginalization, powerlessness, cultural imperialism and violence." 19 "These criteria can be used as a tool to evaluate claims that a group is oppressed.

\section{Faces of Oppression}

\section{Exploitation}

Exploitation is the first face of oppression. It appears in a capitalist society and exists in class division and labor production. There is a transfer of power from the workers to the capitalist. ${ }^{20}$ According to Young, "Workers suffer material deprivation and a loss of control, and hence are deprived of important elements of self-respect." 21 Furthermore, she says that, "Exploitation enacts a structural relation between social groups. Social rules about what work is, who does what for whom, how work is compensated, and the social process by which the results of work are appropriated operate to enact relations of power and inequality." 22 Young takes her cue from

\footnotetext{
${ }^{15}$ Ibid., 42.

${ }^{16} \mathrm{Ibid} ., 43$.

17 Ibid., 47.

${ }^{18} \mathrm{Ibid} ., 40$.

${ }^{19}$ Ibid.

${ }^{20}$ Ibid., 49.

${ }^{21} \mathrm{Ibid}$.

${ }^{22}$ Ibid., 49-50.
} 
Marx's concept of exploitation. However, she notes that it leaves "important phenomena of sexual and social oppression unexplained." 23

For Young, feminists would not have difficulty in showing how women are oppressed through a "systematic and unreciprocated transfer of powers from women to men." 24 The oppression of women is not just seen in the inequality of status, power, and wealth - all of which are a result of their exclusion. ${ }^{25}$ In marriage for example, men's achievements are only possible because women work for them. Marriage can be considered a class relation where "women's labor benefits men without comparable remuneration." 26 This relation can be exploitative in nature: men are able to fully explore their creativity and maximize their capabilities because they are rid of domestic labor, while women are trapped to take on the task of managing the household and raising the children. These tasks deprive her of the time that could have been possibly utilized in accomplishing more fulfilling tasks for herself and her career. Young notes that women are considered as nurturers and yet when "they look to men for emotional support they do not receive it." 27

This argument is also presented in Young's On Female Body Experience: "Throwing Like a Girl" and Other Essays. ${ }^{28}$ She notes that "women serve, nurture, and maintain so that the bodies and souls of men and children gain confidence and expansive subjectivity to make their mark in the world. This homey role deprives women of support for their own identity and projects." ${ }^{29}$ She also argues that the notion of building and dwelling are implicitly gendered, and that the unnoticed labor of women is the basic activity of meaning maintenance. She emphasizes that the "patriarchal gender system allows man a subjectivity that depends on women's objectification and dereliction; he has a home at the expense of her homelessness, as she serves as a ground in which he builds." 30 This could be similar to Beauvoir's idea of housework: "the battle against dust and dirt is never won," 31 it is a never ending repetitive work which may be oppressive

\footnotetext{
${ }^{23}$ Ibid. 50.

${ }^{24}$ Ibid.

${ }^{25} \mathrm{Ibid}$.

${ }^{26}$ Ibid. See also Christine Delphy, Close to Home: A Materialist Analysis of Women's Oppression (Amherst: University of Massachusetts Press).

${ }_{27}$ Ibid., 51. See also Barbara Easton, "Feminism and the Contemporary Family," in Socialist Review, 39 (May/June 1978), 11-36.

28 See Iris Marion Young, On Female Body Experience: "Throwing Like a Girl" and Other Essays (New York: Oxford University Press, 2005).

${ }^{29}$ Iris Marion Young, "House and Home: Feminist Variations on a Theme," in On Female Body Experience, 123.

30 Ibid., 127.

${ }^{31}$ Simone de Beauvoir, The Second Sex, trans. by H.M. Parshley (USA: Vintage Books Edition, 1989), 451-453.
}

(C) 2020 Marella Ada V. Mancenido-Bolaños https://www.kritike.org/journal/issue 26/mancenido-bolanos june2020.pdf ISSN 1908-7330 
to women without them being conscious about it just because they have come to accept the idea that it is a woman's job.

Exploitation can also be seen in the workplace. There are instances when women and men take on the same position, but women are given more workload and are underpaid. These instances lead to poorer job performance and lesser chances of getting a promotion.

\section{Marginalization}

This leads to the second face of oppression which is marginalization. This, for Young, is "perhaps the most dangerous form of oppression." 32 People who are marginalized are those who are not given the opportunity to engage in useful participation in the society. The marginalized may be subjected to severe material deprivation. While redistributive social policies can address material deprivation, it is not the only problem of marginalization. She discusses two categories of injustice which are associated with marginalization.

First, the provision of welfare creates new injustice because it creates an environment where there are those who are dependent on the rights and freedoms that others have. Second, even when material deprivation is somehow mitigated by the welfare state, marginalization is unjust because it blocks the opportunity to exercise capacities in a socially defined and recognized ways. ${ }^{33}$

We can say that when an individual is dependent on the state, on her employer, or on her partner, her "basic rights to privacy, respect and individual choice" are suspended. ${ }^{34}$ Children, sick people, old people, and women recovering from childbirth are individuals who can have the moral right to depend on others for subsistence and support. ${ }^{35}$ Their weakness, however, may be used by the other to dominate them and to completely strip them off of their basic rights. When we allow our government to make laws, we expect them to be mindful of the rights of its people. However, such is not always the case, and the marginalized are often left unheard.

The non-inclusivity of social organizations is also considered unjust. Young notes that marginalization does not just concern issues on distributive justice, "it also involves the deprivation of cultural, practical, and institutionalized conditions for exercising capacities in a context of recognition and interaction." 36 Allowing an individual into the circle may be

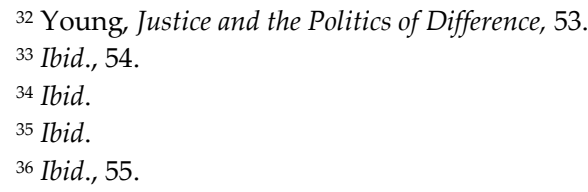


a superficial act of being just, but we must not forget to consider how this person is treated in order to determine whether we have become truly just. In other words, allowing women to take part in politics is not a guarantee that they are going to be heard.

Looking into the politics of positional difference and the politics of cultural difference might help in understanding the concept of marginalization. According to Young, "They both argue that where group difference is socially significant for issues of conflict domination or advantage, equal respect may not imply treating everyone in the same way." 37 It is because of this positionality that certain members of the society are marginalized. People experience culture-based injustice when they do not have the freedom to express themselves. This is also characterized in the third face of oppression which is powerlessness.

\section{Powerlessness}

Powerlessness is characterized by the inability to be autonomous. In a capitalist society, power relations exist between the capitalist, the professional, and the working class. Young describes the powerless as those who "lack authority and power even in this mediated sense, those over whom power is exercised without their exercising it; the powerless are situated so that they must take orders and rarely have the right to give them." 38 She adds that the "powerless status is perhaps best described negatively: the powerless lack the authority, status, and sense of self that professionals tend to have." 39 The professionals may be in a privileged status, for to be a professional requires a college degree and specialized knowledge; as such, they have a certain degree of autonomy over their work and authority over their subordinates. Their privilege is also extended beyond the workplace, such as in banks, restaurants, and hotels. These are not experienced by the nonprofessionals, rendering them powerless. Young cites the case of a black professional who may not immediately get respect from people they encounter because of their race while a nonprofessional white male immediately gets respect until people find out about his real status. This stereotyping extends to women's experiences as well. A properly dressed woman has a higher chance of being respected notwithstanding her

\footnotetext{
${ }^{37}$ Iris Marion Young, "Structural Injustice and the Politics of Difference," in Kwame Anthony Appiah, Seyla Benhabib, Iris Marion Young, Nancy Fraser, Justice, Governance, Cosmopolitanism and the Politics of Difference: Reconfigurations in a Transnational World, ed. by The President of the Humboldt University in Berlin (Berlin: Department of English and American Studies, Faculty of Arts III, Humboldt-Universität zu Berlin, 2007), 81.

${ }^{38}$ Young, Justice and the Politics of Difference., 56.

${ }^{39}$ Ibid., 57.

(C) 2020 Marella Ada V. Mancenido-Bolaños

https://www.kritike.org/journal/issue 26/mancenido-bolanos june2020.pdf

ISSN 1908-7330

$(\mathrm{Cc}) \mathrm{BY}-\mathrm{NC}-\mathrm{ND}$
} 
profession, as opposed to a professional woman who is not decently or properly dressed in accordance to her profession. Nonprofessional women of color have higher chances of being oppressed as opposed to a nonprofessional white woman.

\section{Cultural Imperialism}

The fourth face of oppression is cultural imperialism. This involves the universalization of a dominant group's experience and culture, and its establishment as a norm. ${ }^{40}$ The dominant group's values and experiences affect the other group's perception of things, and there is a superimposition of values and experiences without considering the plight of those who are not part of the dominant group. This domination may affect the decision-making process of the government. For example, in a predominantly Catholic country like the Philippines, where law makers and professionals are predominantly male, the motives behind the enacted laws can become suspicious. Will it benefit, we might ask, the public or the lawmakers? We think of policymaking as a political game. As Young maintained, "government policy and the allocation of resources, according to a pluralist theory, are the outcome of this process of competition and bargaining among interest groups." 41 This is an unjust practice because interest groups do not allow individual citizens to actually take part in the deliberation and decision making. As in the case of the drafting of The Responsible Parenthood and Reproductive Health Act of $2012,{ }^{42}$ legislators wanted to protect their own vested interest which is to uphold the position of the Catholic Church. ${ }^{43}$

Young argues that "those living under cultural imperialism find themselves deprived from the outside, positioned, placed, by a network of dominant meanings they experience as arising from elsewhere, from those with whom they do not identify and who do not identify with them." 44 The sweeping argument that Catholic women must reject artificial family planning is an example of cultural imperialism. A woman's experience is being influenced by her being a Catholic and being a woman in a traditional society. Members of the dominant group, in this case men, cannot truly

\footnotetext{
${ }^{40}$ Ibid., 59.

${ }^{41}$ Ibid., 72.

${ }^{42}$ See The Responsible Parenthood and Reproductive Health Act of 2012, Republic Act No. 10354, 15 th Congress (2012), $<$ https://pcw.gov.ph/law/republic-act-10354 $>$.

${ }^{43}$ In a predominantly Catholic country, politicians often will not risk offending the Catholic Church because the people rely heavily on the Church's opinion during election. To offend the Catholic Church would only equate to fewer votes during election. By choosing to side with the Church, politicians would not enter the risk of losing their positions in the government.

${ }^{44}$ Young, Justice and the Politics of Difference, 72.
}

(c) 2020 Marella Ada V. Mancenido-Bolaños https://www.kritike.org/journal/issue 26/mancenido-bolanos june2020.pdf ISSN 1908-7330 
sympathize because of their own privilege. Men do not go through the same obstacles that women go through. They have lesser chances of experiencing sexual assault, they do not go through the dangers of pregnancy, and they are not as physically exhausted as women when it comes to rearing their children, to mention a few. In the same way that a wealthy woman cannot fathom the need for a better reproductive health law for the underprivileged women of the society because she has no prior experience of the difficulties of these women which include having to go through pregnancy without receiving regular prenatal and postnatal care, having to give birth in an illequipped hospital or birthing clinic, and recover in an overcrowded recovery room. These are just few of the horrors experienced by underprivileged women that people who are not part of their group will never understand.

These unjust experiences can very well be described by Young as "the injustice of cultural imperialism" 45 because the experiences of the oppressed groups do not reach the consciousness of the dominant culture, and yet the experiences of the dominant culture is imposed upon the oppressed groups.

\section{Violence}

The fifth face of oppression is violence. For Young, theorists are usually silent about issues on violence, she believes that "theorists do not typically take such incidents of violence and harassment as matters of social injustice." 46

Young notes that violence is systematic because it is "directed at members of a group simply because they are members of that group." 47 Certain groups, such as women, people of color, and members of the LGBTQ community are susceptible to violence-and this violence is motivated by fear and hatred. This type of violence, according to Young, "approaches legitimacy ... in a sense that it is tolerated." 48 Violence against women and children for example are taken lightly. When women and children become victims of physical and emotional abuse, it is easily dismissed as part of being married or being disciplined. Young believes that "cultural imperialism ... intersects with violence." 49 This is caused by the division between the oppressed and the dominant group. Some members of the dominant group have a sense of entitlement which eventually leads to violence directed at the oppressed group. The male, being part of the dominant group might feel entitled when they demand women to submit to their orders. The rising cases

\footnotetext{
${ }^{45}$ Ibid., 60.

${ }^{46}$ Ibid., 61.

${ }^{47}$ Ibid., 62.

${ }^{48} \mathrm{Ibid}$

${ }^{49}$ Ibid., 63.
}

(c) 2020 Marella Ada V. Mancenido-Bolaños https://www.kritike.org/journal/issue 26/mancenido-bolanos june2020.pdf ISSN 1908-7330 
of racism, moreover, which resulted in violence, is another example. The case of Rodney King that triggered the L.A. 1992 riots and the recent death of George Floyd last May 2020 which resulted in the Black Lives Matter protests are examples of such cases. The nonrecognition of harassment cases filed by black women against white perpetrators can also be considered as a form of violence brought about by cultural imperialism. The silencing and killing of the indigents who are fighting for their ancestral domain is another example of cultural imperialism.

It is not necessary to have all these five types of oppression-namely, exploitation, marginalization, powerlessness, cultural imperialism, and violence-present to say that one is being oppressed. An inclusion of one type can already qualify as oppression. Oppression has become so systematic that it is hardly noticeable to many people. People who are oppressed no longer take it as oppression but as part of the normal structure of things. As such, they simply accept their situation as a given. Women who were abused would sometimes not retaliate for fear of complicating the situation further. This type of imposed structure made it possible for people to be oppressed. It is, therefore, not just about addressing the problem of distributive justice. There is a need to look into our positions in the society. As Young notes, "reform ... can come only through a change in cultural images, stereotypes, and the mundane reproduction of relations of dominance and aversion in the gestures of everyday life." 50

\section{Policies for Women}

This next part of the paper shall present the manifestation of these faces of oppression in the way women are treated in policy-making in the Philippines, particularly in the drafting of the 1987 Constitution and The Responsible Parenthood and Reproductive Health Law of 2012. The problematic debates in the interpellation of the RPRH Law is rooted in Article II Section 12 of the 1987 Constitution which states:

The State recognizes the sanctity of family life and shall protect and strengthen the family as a basic autonomous social institution. It shall equally protect the life of the mother and the life of the unborn from conception. The natural and primary right of the parents in the rearing of the youth for civic efficiency and the development of

${ }^{50}$ Ibid., 63. 


\author{
moral character shall receive the support of the \\ government. ${ }^{51}$
}

The debate about the beginning of human life became so controversial that legal, scientific, and religious points were raised by the legislators. In the end, it was the religious perception that triumphed. Initially, they used the phrase "fertilized ovum" to refer to the beginning of life. Joaquin Bernas, S.J. wanted a more precise phrase that could protect the life of the unborn. Felicitas Aquino contradicted this by saying that "law and jurisprudence are settled that the person do not ripen until one is born." 52 She adds that to give right to the fertilized ovum would mean "to give rights to the potential rather than the actual." 53 Bernardo Villegas was against the point raised by Aquino, and he made use of the genetic argument to prove his point. The committee wanted to make sure that this provision will safeguard the constitution from the possible inclusion of a law that legalizes abortion. Felicitas Aquino and Minda Luz Quesada wanted to secure the rights of women by arguing for the exemption of the cases of women whose pregnancies were a result of rape. Villegas insisted that such exemption "would be always the key to open the floodgates to millions of abortion ... cases of pregnancy resulting from rape are extremely rare." 54 Instead of considering the suggestions of the women in the committee, what he wanted was to create a caring society to look after these broken women $-\mathrm{a}$ reactionary solution to an otherwise preventable problem. Such caring society, moreover, is a band aid solution. It cannot systematically address the problems present in a prejudiced community. Quesada gave a striking comment, "It is very easy for men who are not raped or who will never be raped to talk about a caring society who will take care of a child who is a product of multiple rape. What right have we to make a choice for women who are victims of multiple rape and what it does to them for the rest of their lives?" 55 With this, Blas Ople wanted his colleagues to reconsider the case. He asks:

Should the constitution interpose itself between this mother ... so that she is denied the right to life of peace and serenity and her own pursuit of happiness because

511987 Constitution of the Republic of the Philippines, Art. II, § 12. See also Marilen J. Dañguilan, The RH Bill Story: Contentions and Compromises (Manila: Ateneo de Manila University Press, 2018), 11.

52 Dañguilen, The RH Bill Story: Contentions and Compromises, 16. Quotations from and references to lawmakers, as well as quotations from the Constitution, are hereafter taken from Dañguilen, The RH Bill Story: Contentions and Compromises.

${ }^{53}$ Ibid.

${ }^{54}$ Ibid., 21.

${ }^{55}$ Ibid., 23.

(C) 2020 Marella Ada V. Mancenido-Bolaños https://www.kritike.org/journal/issue 26/mancenido-bolanos june2020.pdf ISSN 1908-7330

(c) BY-NC-ND 
there is a constitutional provision that prevents her from correcting or rectifying a socially imposed wrong that had been committed against her?" 56

Quesada and Villegas once again exchanged arguments. Quesada questions whether Villegas was not "denying woman the equal protection of the law, the due process of the law? The Gentleman is giving due process to the unborn but not to the woman; that is, that she makes a choice." 57 Villegas replied that "There is absolutely no right to murder and therefore that woman has absolutely no right to murder the child." 58

Aside from Article II, Section 12, the committee also deliberated on Sections 9 and 11. Section 11 seeks to create an "agreement on women's right to equal protection with men." 59 Aquino adds that "the intent of this provision was to repeal all discriminatory and anti-feminist laws in the Civil Code and the Revised Penal Code. " 60 Aquino clarified that the provision does not aim for absolute equality, what must be done is to "nullify the place of women on a pedestal ... the law has done very little except to perpetuate the myth that women are helpless and therefore should be put on a pedestal." 61 Aquino also noted that in the Civil Code, if the husband's income is sufficient, he can object to his wife's profession. The wife's mobility is also subordinate to her husband's. The husband should manage the conjugal property while the wife takes care of the household. ${ }^{62}$ This idea was once again met with chauvinism. Adolfo Azcuna clarified the provision by saying that "I believe they are still within the ambit of reasonable classification since we cannot erase the difference between men and women." 63 Ambrosio Padilla agrees with Azcuna, and implies that men and women have predetermined roles in the family where the men shall provide while the woman takes care of the household. To him, this order is important to keep the family in order. ${ }^{64}$

We can see that these arguments are only pointing to one direction: the predetermined role of women in the society, which is to become a housewife and bear children. A discussion on allowing a woman to decide for her body was immediately negated by the male-dominated committee. This kind of argumentation on the floor remained the same for the next decade.

\footnotetext{
${ }^{56}$ Ibid., 24.

${ }^{57} \mathrm{Ibid}$.

${ }^{58}$ Ibid.

${ }^{59} \mathrm{Ibid} ., 33$.

${ }^{60} \mathrm{Ibid}$.

${ }^{61}$ Ibid., 34

${ }^{62} \mathrm{Ibid}$.

${ }^{63}$ Ibid.

${ }^{64}$ Ibid., 35.
} 
The committee that drafted the 1987 Constitution was composed of forty-seven members wherein only five were women; among the five women, only two stood to voice out their arguments on pivotal provisions. A similar scenario was in place during the drafting of The Responsible Parenthood and Reproductive Health Law of 2012. It took four congresses, from 2001 to 2011, to pass the law.

Bills to mitigate the population were filed prior to bills on reproductive health. Leticia Ramos-Shahani "filed Resolution 39 that urged the strengthening of national population program by implementing the Commission on Population's Policy Statement of April 1987." 65 Shahani intended to support Population Commission's implementation of the "National Population Plan which included family planning and responsible parenthood Program for married couples of reproductive age."66 The resolution was approved but tapered to accommodate the demands of the Catholic Church. According to Shahani, her colleagues resisted on population-related issues because for them, advocacies on "population, development, and women are flower issues, unimportant, and essentially fluff." 67

Shahani was later convinced that her colleagues will not rally behind her on these issues. Together with Benjamin De Leon, she organized the Philippine Parliamentarians Conference of the Philippine Congress where they "promoted the right of spouses to choose and plan their desired family sizes within their ethical beliefs, to empower women through education and incomes and to strengthen NGOs that would promote and provide family planning information and services." 68

However, the congress remained unmoved even with the advocacies pushed for by PARLCON. They did not present any initiatives on population and women's reproductive rights because they did not want to offend the sensibilities of the Catholic Church. Bishop Gilbert Garcera believes that "The huge Philippine population could be part of God's plan for Filipinos to be caregivers to ageing nations whose populations had become stagnant. Many Filipino women would make good wives for foreigners in countries that have low population." ${ }^{69}$ To say that this claim is an insult to women is an understatement.

During the time of President Fidel V. Ramos, he appointed Juan Flavier as the Secretary of Health. Flavier's programs caught the attention of the Catholic Church. He spearheaded the ABC campaign which stands for

\footnotetext{
${ }^{65} \mathrm{Ibid} ., 36$.

${ }^{66}$ Ibid.

${ }^{67}$ Ibid., 37.

${ }^{68} \mathrm{Ibid}$.

${ }^{69}$ Ibid., 38.
}

(C) 2020 Marella Ada V. Mancenido-Bolaños https://www.kritike.org/journal/issue 26/mancenido-bolanos june2020.pdf ISSN 1908-7330 
"Abstain, Be faithful, but if you could not abstain and be faithful, use Condom." 70 For the Catholic Church, Flavier was "encouraging promiscuity and fostering a contraceptive mentality and immorality. They accused him of promoting abortion on the sly through artificial contraceptives." 71 When Flavier organized a delegation to attend the Preparatory Conference of the International Committee on Population and Development in New York, the Catholic Church claimed that the behavior of the delegates was "abominable, censurable and disgraceful. They accused the delegates of supporting the legalization of abortion on demand, institutionalizing homosexual relationship, and going against the family."72 One of the delegates, Cecile Joaquin-Yasay, narrates "I had a miscarriage. I was 42 years old then. I was 5 $1 / 2$ months pregnant and I was travelling a lot. And I remember what the Catholic Church said. The reason I had a miscarriage was that I was not behaving well, and God punished me."73 No words can explain how malicious the Catholic Church's comment was.

From this point on, it was already a battle against religious beliefs; it was no longer a fight for women's rights alone but a fight against the dogmas of the Catholic Church. Never mind if a woman gives birth to a dozen children and live in poverty, as long we follow the teachings of the Catholic Church. Never mind if the maternal mortality ratio in the country is not reduced, as long as we do not offend the sensibilities of the religious. These claims can be supported by senate hearings from 1992-1994 when Senator Francisco Tatad and Senator Jose Lina grilled every resource person on the grounds of religious beliefs, especially when these people, without looking into the scientific basis on the use of pills and IUD, have already concluded that these are abortifacient. They rejected the idea of providing funds for the purchase of contraceptives to be distributed through the family planning programs of the government. Tatad proposes "that private organizations should be free because private individuals should be free to practice contraception if they so desire. There is no law that should bind an individual to observe certain things inside the bedroom .... I don't believe the taxpayers' money should be spent on it (contraceptives) That's how I interpret the Constitutional provisions. But private initiative, that's ok." 74 This statement clearly shows the demarcation line between the privileged and underprivileged women.

During the presidency of Ramos, the population bill in the Senate never made it to the plenary. "It was never calendared as part of a regular or

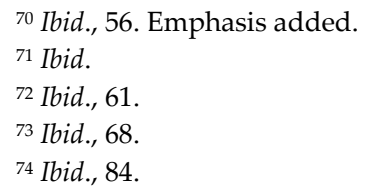




\section{THE OPPRESSION OF WOMEN IN THE RPRH ACT OF 2012}

special conduct of business. In the lower house, the population bill was never taken up." 75

The RH bill did not make any progress during the short-lived administration of President Joseph Ejercito Estrada and President Gloria Arroyo either. The latter was so determined to maintain a good relationship with the Catholic Church.

In 2001, Bellaflor Angara-Castillo, Kristel Lagman-Luistro, Darlene Antonino Custodio, Nereus Acosta, and Loretta Rosales filed the Reproductive Health Care Act of $2001^{76}$ which aims "to institutionalize reproductive rights and health in the country through sexuality education, family planning, maternal death reduction and measures to prevent HIV/AIDS among others." 77

When it was brought to the floor for its public hearing on 27 August 2002 , the questions raised by lawmakers once again gravitated towards the possibility of legalizing abortion, as well as encouraging premarital sex through the introduction of the use of condoms and artificial contraceptives, not to mention its immorality. Angara-Castillo challenged the legislators to point which specific provision in the bill mentions such, in order that they could explain the intention of the provision. Rosales, on the other hand, points out that abortion is already happening to at least one in six pregnancies; she adds that the intention of the bill was to stop this from happening as it aims to "take care of the woman and her reproductive rights." 78

The bill went through the second and third hearing, but the arguments posed remained the same until those who opposed the bill succeeded in stalling it in Congress.

On 3 September 2002, Senator Rodolfo Biazon "introduced the Senate Bill No. 2325, The Reproductive Health Care Act."79 Senator Aquilino Pimentel wanted the senators to reject the bill. He said that he was "not quite comfortable with the basic premise of the bills ... that women have absolute discretion on what they want to do with their bodies." 80 During his speech, he was invoking religion as a basis for the bill. According to him, "there are limits to what women may do with their bodies - or men for that matterand the limits are what the law imposes." ${ }^{81} \mathrm{He}$ cites that these laws are found

${ }^{75}$ Ibid., 90.

76 An Act Establishing a Reproductive Health Care Act, Strengthening Its Implementing Structures, Appropriating Funds Therefor and for Other Purposes, House Bill No. 4110, $12^{\text {th }}$ Congress (2001).

77 Dañguilan, The RH Bill Story: Contentions and Compromises, 107.

${ }^{78}$ Ibid., 115.

${ }^{79}$ Ibid., 147.

${ }^{80}$ Ibid., 149.

${ }^{81} \mathrm{Ibid} ., 152$.

(C) 2020 Marella Ada V. Mancenido-Bolaños https://www.kritike.org/journal/issue 26/mancenido-bolanos june2020.pdf ISSN 1908-7330

(c) $)$ BY-NC-ND 
in the Revised Penal code and even in the ten commandments. He adds:

When we talk of religious convictions in relation to founding of families we are talking here of policy. We are not talking of individual preferences or individual religions. We are talking of the fact that the Philippines is a very large Christian population, in matters of policy, one has to abide, if it is the government, it has to abide by the will of the greater number of people in a given community. 82

Was it not proper to also take into consideration the other 19\% of Filipinos who are not Catholics? Was it not worthwhile to consider that this remaining percentage of the population are in favor of the RH Bill? Aside from the bill filed by Biazon, there were twenty-one more bills related to reproductive health. In one of the hearings, Senator Pia Cayetano stressed on the burden that women have to bear in raising a family of six to eight members. According to her, a family needs at least Php 18,000.00 to live in decent conditions. However, the minimum wage at this time was only pegged at Php $8,000.00$. Women are thus burdened to make ends meet. Alma Infante, a DSWD representative, agreed with Cayetano. She notes how pitiful the state is as she urged senators that it must be upon them to help support women. Unfortunately, the twenty-one bills filed in the senate did not progress. ${ }^{83}$

Despite the coldness of the administration to the bill, those who believed in the necessity of enforcing an institutionalized reproductive health law would not easily give up on their ideals. Esperanza Cabral, the newly appointed Department of Health secretary issued an administrative order "enabling midwives to administer lifesaving drugs and medicines to prevent maternal and newborn death and disabilities." 84 During the $13^{\text {th }}$ Congress, four representatives filed four different versions of the reproductive health bill. They were Edcel Lagman, Josefina Joson, Ferjenel Biron, and Eduardo Requero. During the $14^{\text {th }}$ Congress, Edcel Lagman, Janette Garin, and Risa Hontiveros authored House Bill 5043. ${ }^{85}$ This is a consolidation of three other bills filed in the Congress. ${ }^{86}$ All these versions did not progress in Congress.

\footnotetext{
${ }^{82}$ Ibid.

${ }^{83}$ Ibid., 173.

${ }^{84}$ Ibid., 215.

85 An Act Providing National Policy on Reproductive Health, Responsible Parenthood and Population Development and for Other Purposes, House Bill No. 5043, 14 ${ }^{\text {th }}$ Congress (2008), $<$ http://www.congress.gov.ph/download/14th/hb05043.pdf $>$.

${ }^{86}$ House Bill No. 17 was filed by Edcel Lagman, House Bill No. 812 was filed by Janette Garin, and House Bill No. 2753 was filed by Narciso Santiago III, Mark LLandro Mendoza, and Eleano Jesus Madrona. See Dañguilan, The RH Bill Story: Contentions and Compromises, 174
} 
It was only during the administration of President Benigno Aquino III when the RH Bill was passed by both houses of Congress. Aquino believed in the importance of providing better reproductive health care for women. It must be remembered that though his family had a good relationship with the Catholic Church, this did not hinder him from supporting the RH Bill even as he received threats of his excommunication. ${ }^{87}$

When Aquino was elected, he was determined to pass the RH Bill into law. In a speech delivered to the graduates of the University of the Philippines he said:

Naalala ko tuloy ang batang nakilala ko sa Baseco. Talagang nakapinta sa mukha nya ang hinagpis. Papaano ba naman, labing-anim na taon pa lang siya, dalawa na ang nagging anak niya. Paano niya papakainin ang mga bata, paano paaaralin, gayong wala silang trabaho ng kaniyang asawa? Sino po ba ang nagkulang? Sino ang nagtulak sa kanila sa ganitong sitwasyon? Paano nabagsak sa kanilang balikat ang ganitong pananagutan? At ang pinakamalaking tanong: Ano ba ang aking magagawa?

Buo ang loob ko na maisabatas ang prinsipyo ng Responsible Parenthood. 88

During the deliberations on the amendments, it shows that those opposed to the bill were using Church doctrines and religious beliefs to debunk the bill in toto. Fenny Tatad, for example urged the bishops to convince the members of the congress to vote against the bill. Amado Bagatsing was insisting on the link between contraceptives and abortion. Victorino Dennis Socrates even cited predictions of a visionary as he warned the congress of more disasters to happen if they continue discussing the bill. Mitos Magsaysay had the same view saying "Heaven must be crying. We should undo what has been done." 89

While there was development in the Lower House, Senator Miriam Defensor Santiago together with Senator Pia Cayetano and Senator Panfilo Lacson authored the Senate Bill 2865 or, An Act Providing for a National

\footnotetext{
${ }^{87}$ Dañguilan, The RH Bill Story: Contentions and Compromises, 232.

${ }^{88} \mathrm{Ibid} ., 251$. DSWD Secretary Corazon Soliman could attest that this encounter really happened as she was with Aquino when he visited Baseco.

${ }^{89} \mathrm{Ibid} .$, 303. Both Socrates and Magsaysay are against the RH Bill. Their comments are their reactions after the Lower House voted on to end the debate and proceed to the drafting of the amendment on the bill. The votation happened a day earlier than scheduled.
} 
Policy on Reproductive Health and Population and Development. ${ }^{90}$ In Santiago's sponsorship speech, she focused on the primacy of conscience in Catholic theology, constitutional and international law, and socioeconomic aspects of reproductive health. ${ }^{91}$ Her lengthy sponsorship speech was delivered in three parts in anticipation of the questions to be raised by the supreme court.

During the debates, the senators raised questions on the same issues: the sanctity of life based on Article II, Section 12 of the 1987 Constitution, the beginning of life, the potential life in sperm cells, abortifacient effect of artificial contraceptives, and violation of the teachings of the Catholic Church, among others. All these issues were raised without any regard for the real intentions of the bill. Without considering the cases of women who were deprived of a comprehensive reproductive health care for decades. The determination of the advocates remains steadfast, the support of the president was discernible. Finally, on 21 December 2012 it has become a law. ${ }^{92}$

Despite the approval of then President Aquino, James and Lovely Ann Imbong, filed a petition to the Supreme Court questioning the constitutionality of the RH Law. The Supreme Court then ordered a 120-day status quo ante order which means that the law is not to be implemented in the next 120 days. Oral arguments were held from July to August 2013, until the Supreme Court ruled that the RH Law was partly unconstitutional. In 2015, the Supreme Court was once again faced with a petition filed by the Alliance for the Family Foundation Philippines, Inc. This petition wanted to stop the purchase, sale, distribution, dispensation, and administration of artificial contraceptives. On 17 June 2015 a temporary restraining order was issued. Then, 10 November 2017, the Food and Drug Authority issued an advisory stating that the 51 contraceptives it reevaluated were not abortifacients. This has signaled the automatic lifting of the TRO. ${ }^{93}$

\section{Reports on the Implementation of The Responsible Parenthood and Reproductive Health Act of 2012}

In the $4^{\text {th }}$ Annual Report on the Implementation of the Responsible Parenthood and Reproductive Health Act of 2012, published in 2017, it notes that there is an increase in budget allocation from Php 29.7 billion in 2016 to Php

\footnotetext{
${ }^{90}$ An Act Providing for a National Policy on Reproductive Health and Population and Development, Senate Bill No. 2865, 15 ${ }^{\text {th }}$ Congress (2011), < https://www.senate.gov.ph/ lis/bill_res.aspx?congress $=15 \& q=S B N-2865>$.

${ }_{91}$ Dañguilan, The RH Bill Story: Contentions and Compromises, 407.

${ }_{92}$ See The Responsible Parenthood and Reproductive Health Act of 2012, Republic Act No. 10354, 15 th Congress (2012), <https://pcw.gov.ph/law/republic-act-10354>.

${ }^{93}$ Dañguilan, The RH Bill Story: Contentions and Compromises, 496-520.

(c) 2020 Marella Ada V. Mancenido-Bolaños https://www.kritike.org/journal/issue 26/mancenido-bolanos june2020.pdf ISSN 1908-7330 
374 billion in 2017. This covers funding for Family Health and Responsible Parenting, Expanded Program on Immunization, Health Facilities Enhancement Program, as well as the RPRH-related programs of POPCOM. The government also allocated funds for gender and development-related activities of the Philippine Commission on Women and HIV/AIDS program of the DOH. ${ }^{94}$ Maternal health care and services also improved, and there is an increase in the number of women giving birth in health care facilities which are staffed by trained health care professionals. It was also reported that the use of contraceptives among married women increased to $40.4 \%$. There was, moreover, a decrease in the number of women, aged 15 to 19, who began childbearing. However, there is an increase of repeat pregnancy because there remains to be an estimated 1.4 million young women who are willing to avail of family planning but are unable to use any family planning method. ${ }^{95}$ As such, while the numbers appear promising, it does not guarantee that the provisions are working well. There is always the threat of budget cuts during the annual budget hearings, and there are still institutions which are reluctant on the implementation of these policies. Although there is a decrease in the number of teenage pregnancies, there are still ten-year old girls getting pregnant, and there are still unreported cases of violence against young women. We can only wish for the continued support of the Congress and the local government units to conscientiously implement the law and allocate enough budget to fund it, because the battle should not end with the approval of the bill.

\section{Faces of Oppression in the Drafting of The Responsible Parenthood and Reproductive Act of 2012}

From the foregoing discussions, one could easily recognize the fact that the state, rather than by sincerely looking at the problems experienced by women, have instead opted to prioritize its relationship with the Catholic Church, thereby extending a hand in the oppression of women. Women are continuously exploited through unpaid or underpaid labor, domestic or otherwise. Women are still dependent on others for their sustenance, which means that they still depend on the state or the private sector to keep them afloat. Being the primary nurturer in the household, the burden of poverty lies on the shoulders of women, as they are the ones who try to make ends meet. Women are still marginalized by not being able to fully participate in the society. During the 1987 Constitutional Convention only five of the 47

\footnotetext{
${ }^{94}$ See Department of Health, $4^{\text {th }}$ Annual Report on the Implementation of the Responsible

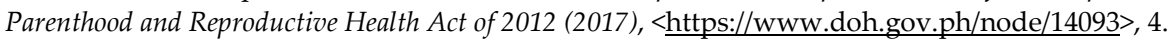

${ }^{95}$ Ibid., 8-9.

(C) 2020 Marella Ada V. Mancenido-Bolaños

https://www.kritike.org/journal/issue 26/mancenido-bolanos june2020.pdf

ISSN 1908-7330

(c) $)$ BY-NC-ND
} 
members are women, ${ }^{96}$ and the transcripts presented above show how women were silenced by the male members of the committee. We see the struggle of underprivileged women when they were denied access to better reproductive health services, when maternal deaths were not addressed, when poor birthing facilities were not noticed, and when access to artificial family method was banned from being sold and distributed. When Francisco Tatad emphasized that private individuals may access family planning methods but refused to fund the distribution of artificial contraception to underprivileged women using taxpayers' money, he has deprived them and their children of a better quality of life. All these incidents render a woman powerless because she is not given authority - not even the authority over her own body or even her own future. There may be laws and religious doctrines which speak of what women can and cannot do to their bodies, but is it wrong to argue that imposing these laws and beliefs violate women's rights to decide for themselves? Why must a woman not be in control of what happens to her body? When Bernardo Villegas denied the exemption of women who were victims of multiple rape to resort to abortion, and instead vouched for the encouragement of a caring environment in a prejudicial society, he has denied women to live a more psychologically sound life. Sandra Lee Bartky notes that in cases of an unwanted pregnancy, a woman bears something within, "an alien, something she doesn't want there, indeed, a parasite living within her body .... this sense of housing an alien and unwelcome other might well grow. The fetus is hers in a physiological sense, but not necessarily in a psychological sense." ${ }^{97}$ Quesada's rebuttal was only fitting-Villegas will not understand the struggle because men like him will never be raped and bear the child of the rapist. Women can be powerless just by the fact that they are women. Her body is sexualized and objectified, she is predisposed to abuse even before she learns how to fight for herself. We see in the transcription above that even learned women in the committee were treated like preys by the predominantly male group. These are results of cultural imperialism, in which the predetermination of women's roles does more damage to herself than she can ever imagine. When the lawmakers refer to the doctrines of the bible assigning women to become wives and mothers, that already discounts her of all her other potentials. When a bishop rejects solutions to reproductive health and population issues, and instead argues that overpopulation in the

96 "The 1987 Constitution of the Republic of the Philippines - Members of the Constitutional Commission," in Official Gazette, <https://www.officialgazette.gov.ph/ constitutions/the-1987-constitution-of-the-republic-of-the-philippines/the-1987-constitution-ofthe-republic-of-the-philippines-members-of-the-constitutional-commission/>.

${ }_{97}$ Sandra Lee Bartky, "Iris Young and the Gendering of Phenomenology," in Dancing with Iris: The Philosophy of Iris Marion Young, ed. by Ann Ferguson and Mechthild Nagel (Oxford: Oxford University Press, 2009), 45.

(c) 2020 Marella Ada V. Mancenido-Bolaños https://www.kritike.org/journal/issue 26/mancenido-bolanos june2020.pdf ISSN 1908-7330 
Philippines is God's plan, and that Filipino women can be sent abroad to become caregivers or marry foreign men from unpopulated countries, he is devaluing women. As former President Fidel V. Ramos said, "We had no prohibitions with Reproductive Health, because what we were always discussing or implementing here, from ' 92 to '98, was the quality of Filipino population." 98 Ramos saw the importance of protecting women, it is just that the country was not yet ready during his time. Data shows that there is a decreasing number of cases of violence against women in the country. However, this decreasing number is caused by the women's refusal to report their cases to the police, as there are notions that spousal abuse should be something settled between the married couples. According to the 2017 National Demographic and Health Survey, conducted by the Philippine Statistics Authority, "Women's experience of physical violence decreased slightly over time, from 20\% in 2008 and 2013 to 17\% in 2017. Similarly, women's experience of physical violence in the 12 months preceding this survey has declined slightly, from 7\% in 2008 to 5\% in 2017." 99 Moreover, according to Diana Mendoza, while the respondents were aware of the legal implications of Violence Against Women and Their Children (VAWC), they nevertheless sought help instead from family, friends, and neighbors. Unfortunately, only $6 \%$ of the women sought help from the police. ${ }^{100}$ The fact remains that women are still susceptible to violence.

The discussions above show the "systemic character of oppression." As Young notes, the "oppressed group need not have a correlate oppressing group. While structural oppression involves relations among groups, these relations do not always fit the paradigm of consciousness and intentional oppression of one group by another." 101 Such is the case because the division between groups have been so rooted in the consciousness of people that oppression has been normalized and thus, tolerated.

Women and women's rights advocates suffered the same form of oppression within the halls of congress during the deliberations on the RPRH Bill. They were accused of including certain provisions that were never there in the first place. They were accused of inserting provisions that would legalize abortion, encourage promiscuity and premarital sex, and promote

\footnotetext{
98 See GatesFoundation, "A Patient Revolution: Reproductive Rights in the Philippines," in YouTube, 3:20 (29 May 2013), <https://www.youtube.com/ watch?v=chFCrK3R7a4>.

${ }^{99}$ Philippine Statistics Authority (PSA) and ICF, Philippines National Demographic and Health Survey 2017 (Quezon City, Philippines and Rockville, Maryland, USA: PSA and ICF, 2018), 220 .

100 Diana J. Mendoza, “The problem of violence against women and children," in BusinessWorld (2 December 2019), <https://www.bworldonline.com/the-problem-of-violenceagainst-women-and-children/>.

101 Young, Justice and Politics of Difference, 41-42.
}

(c) 2020 Marella Ada V. Mancenido-Bolaños

https://www.kritike.org/journal/issue 26/mancenido-bolanos june2020.pdf ISSN 1908-7330

(cc) Br-NC-ND 
immorality by using artificial family methods. However, these were not part of the intention of the bill. Junice Melgar underscores that the law revolved on three things: maternal health, family planning, and sexuality education. ${ }^{102}$ More than anything else, we should consider the law as a basic right of every woman. The law is pro-woman: it protects women from unwanted pregnancy, it protects her from incurring sexually transmitted diseases, and it gives her the knowledge and the freedom to choose for herself. Moreover, the law pushes for the establishment of safe places for women, such as health facilities, thereby lessening maternal deaths. As Elizabeth Angsioco lamented, "how ironic that women gave life, but in such a process, many died." 103 To educate the youth on sexuality is one way to increase awareness about the dangers of engaging in sexual activities at an early age. This kind of awareness will lessen the chances of unwanted and medically dangerous pregnancy among the youth. Teaching them about sexuality is not to encourage them to engage in the act, as those who strictly abide by religious doctrines might believe, but it is meant to teach them about its dangers. Clearly, the presumptions given by those who were against the law were never really part of the law.

If the provisions are properly implemented, they shall guarantee assistance that would enable women to take full control over their reproductive health. Moving forward, we can only wish that those who are members of the dominant group in the Congress will continue to allot funds for women's health and that leaders in the local government units and all the agencies involved will see to it that all the provisions set forth in the law will be properly implemented for benefit of women. Let us remember Rosalie Cabiñan and her twenty-two children, as well as Nerissa Gallo and her sixteen children: ${ }^{104}$ they could have had a better chance at life if only those who are in power listened to and recognized their story. Let us be reminded that "Social justice ... requires not the melting away of difference, but institutions that promote reproduction of and respect for group differences without oppression." 105

Department of Philosophy, University of Santo Tomas, Manila, Philippines

\footnotetext{
102 See GatesFoundation, "A Patient Revolution: Reproductive Rights in the Philippines."

${ }^{103}$ Ibid.

104 See ibid.

105 Young, Justice and Politics of Difference, 47.
}

(c) 2020 Marella Ada V. Mancenido-Bolaños https://www.kritike.org/journal/issue 26/mancenido-bolanos june2020.pdf ISSN 1908-7330 


\section{Acknowledgments}

I wish to thank Dr. Marilen Dañguilan for her generosity of sending me a copy her book during the Enhanced Community Quarantine. I also wish to thank Dr. Eden Divinagracia of Philippine NGO Council on Population, Health and Welfare for allowing me to witness the real situation of women, Ms. Chi Laigo-Vallido, Advocacy and Communication Specialist at the Forum for Family Planning and Development for making it possible for me to get a copy of Dr. Marilen Dañguilan's book, and for the work she has done for the women in the community. Lastly, my utmost gratitude to Dr. Josephine Acosta-Pasricha for the countless lectures on feminism and women empowerment, for making me realize that women can. Thank you for your valuable suggestions which helped me in developing this paper.

\section{References}

An Act Establishing a Reproductive Health Care Act, Strengthening Its Implementing Structures, Appropriating Funds Therefor and for Other Purposes, House Bill No. 4110, $12^{\text {th }}$ Congress (2001).

An Act Providing for a National Policy on Reproductive Health and Population and Development, Senate Bill No. 2865, 15 ${ }^{\text {th }}$ Congress (2011), < $\quad$ https://www.senate.gov.ph/lis/ bill res.aspx?congress $=15 \& q=S B N-2865>$.

An Act Providing National Policy on Reproductive Health, Responsible Parenthood and Population Development and for Other Purposes, House Bill Number 5043, 14 $4^{\text {th }}$ Congress (2008), $<$ http://www.congress.gov.ph/download/14th/hb05043.pdf $>$.

Bartky, Sandra Lee, "Iris Young and the Gendering of Phenomenology," in Dancing with Iris: The Philosophy of Iris Marion Young, ed. by Ann Ferguson and Mechthild Nagel (Oxford: Oxford University Press, 2009).

de Beauvoir, Simone, The Second Sex, trans. by H.M. Parshley (USA: Vintage Books Edition, 1989).

Dañguilan, Marilen J., The RH Bill Story: Contentions and Compromises (Manila: Ateneo de Manila University Press, 2018).

Delphy, Christine, Close to Home: A Materialist Analysis of Women's Oppression (Amherst: University of Massachusetts Press).

Department of Health, $4^{\text {th }}$ Annual Report on the Implementation of the Responsible Parenthood and Reproductive Health Act of 2012 (2017), $<$ https://www.doh.gov.ph/node/14093>.

Easton, Barbara, "Feminism and the Contemporary Family," in Socialist Review, 39 (May/June 1978). 
Ferguson, Ann, "Is There a Lesbian Culture?" in Lesbian Philosophies and Culture, ed. by Jeffner Allen (Albany: State University of New York).

GatesFoundation, "A Patient Revolution: Reproductive Rights in the Philippines," in YouTube, 3:20 (29 May 2013), $<$ https://www.youtube.com/watch?v=chFCrK3R7a4 $>$.

Mendoza, Diana J., "The problem of violence against women and children," in BusinessWorld (2 December 2019), $<$ https://www.bworldonline.com/the-problem-of-violence-againstwomen-and-children/>.

Philippine Statistics Authority (PSA) and ICF, Philippines National Demographic and Health Survey 2017 (Quezon City, Philippines and Rockville, Maryland, USA: PSA and ICF, 2018).

"The 1987 Constitution of the Republic of the Philippines - Members of the Constitutional Commission," in Official Gazette,

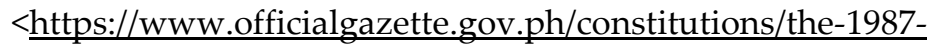
constitution-of-the-republic-of-the-philippines/the-1987constitution-of-the-republic-of-the-philippines-members-of-theconstitutional-commission/>.

The Responsible Parenthood and Reproductive Health Act of 2012, Republic Act No. 10354, 15 th $^{\text {th }}$ Congress (2012), $<$ https://pcw.gov.ph/law/republic-act-10354>.

Young, Iris Marion, "Gender as Seriality: Thinking About Women as a Social Collective," in Signs, 19:3 (1994). "House and Home: Feminist Variations on a Theme," in On Female Body Experience: "Throwing Like a Girl" and Other Essays (New York: Oxford University Press, 2005). Justice and the Politics of Difference (New Jersey: Princeton University Press, 1990). On Female Body Experience: "Throwing Like a Girl" and Other Essays, (New York: Oxford University Press, 2005).

"Structural Injustice and the Politics of Difference," in Kwame Anthony Appiah, Seyla Benhabib, Iris Marion Young, Nancy Fraser, Justice, Governance, Cosmopolitanism and the Politics of Difference: Reconfigurations in a Transnational World, ed. by The President of the Humboldt University in Berlin (Berlin: Department of English and American Studies, Faculty of Arts III, Humboldt-Universität zu Berlin, 2007). 